\title{
The Peoples' Democratic Party (HDP) and the 2015 elections
}

\section{loannis N. Grigoriadis}

To cite this article: Ioannis N. Grigoriadis (2016) The Peoples' Democratic Party (HDP) and the 2015 elections, Turkish Studies, 17:1, 39-46, DOI: 10.1080/14683849.2015.1136086

To link to this article: https://doi.org/10.1080/14683849.2015.1136086

曲 Published online: 26 Feb 2016.

Submit your article to this journal $₫$

Џlll Article views: 524

Q View related articles $\asymp$

View Crossmark data $\rtimes$

Citing articles: 4 View citing articles $\longleftarrow$ 


\title{
The Peoples' Democratic Party (HDP) and the 2015 elections
}

\author{
loannis N. Grigoriadis \\ Department of Political Science and Public Administration, Bilkent University, \\ Ankara, Turkey
}

\begin{abstract}
The Peoples' Democratic Party (Halkların Demokratik Partisi [HDP]) was one of the leading actors in Turkey's double parliamentary elections in 2015. Under the leadership of Selahattin Demirtaş, it has enjoyed great success, crossing the ten percent threshold and entering parliament in the June 7, 2015 elections. Yet the hype was mitigated by the party's poorer results in the November 1, 2015 elections. This electoral performance manifested the strengths as well as the limits of the HDP's ability to maintain its support in a polarized political environment. Yet the HDP remains an indispensable actor for the peaceful resolution of the Kurdish issue.
\end{abstract}

ARTICLE HISTORY Received 7 December 2015; Revised 15 December 2015; Accepted 22 December 2015

KEYWORDS HDP; Turkey; elections; Kurds; Demirtaş

\section{Introduction}

The Peoples' Democratic Party (Halklarin Demokratik Partisi [HDP]) was one of the leading actors in the two parliamentary elections that took place on June 7 and November 1, 2015. Its success in crossing the ten percent threshold on June 7 became a milestone in the history of the pro-Kurdish and left-wing political movements in Turkey and was one of the main reasons for the failure of the incumbent Justice and Development Party (Adalet ve Kalkınma Partisi [AKP]) to win a parliamentary majority. Its copresident Selahattin Demirtaş emerged as the new charismatic figure of Turkish politics. While in the November elections the HDP maintained its percentage above ten percent, the decline in its support contributed to yet another comfortable parliamentary majority for the AKP. However, the HDP remains a crucial actor for the resolution of the Kurdish question as well as for the future of the left in Turkey. 


\section{From the fringes to the center of Turkish politics}

The HDP is the last in a long series of left-wing political parties that aimed to represent Turkey's Kurdish minority. All these parties had to compete under adverse circumstances and often had limited freedom to campaign. ${ }^{1}$ In addition, pro-Kurdish political parties had to face the formidable barrier of Turkey's electoral law. One of the main legacies of the 1980-83 military regime has been a ten percent threshold for the entry of political parties into the Turkish National Assembly. This was meant to prevent the rise of Islamist and Kurdish nationalist parties to prominence in Turkish politics. While this provision is not constitutionally enshrined, it has remained one of the intrinsic features of the Turkish political party system. Eventually, Islamist political parties were able to cross the threshold and turn this provision from a political liability to an asset as they grew bigger and consequently marginalized other conservative political parties. On the other hand, pro-Kurdish political movements repeatedly failed to cross the ten percent threshold, as a large number of voters of Kurdish descent objected to their left-wing, secular orientation and voted instead for other parties on religious and/or economic grounds. This led pro-Kurdish political parties to formally abstain from elections and support, instead, independent candidates in the provinces inhabited by sizable Kurdish populations. This led in 2011 to the election of 36 independent MPs, most of whom later formed a parliamentary group.

An additional obstacle for Kurdish political parties has been the Turkish judiciary. Several pro-Kurdish political parties have been banned by the Constitutional Court since Turkey's return to civilian rule in 1983 as their statutes, programs and activities have been found to be against the provisions of Article $68 \$ 4$ of the Turkish Constitution. ${ }^{2}$ The HDP is thus the latest in the line of these parties. It was formally founded in August 2012, but gained more prominence after the delegates of the Kurdish-oriented Peace and Democracy Party (Barış ve Demokrasi Partisi [BDP]) decided to join the HDP in April 2014.

While the HDP has, since its inception, aimed to shed the badge of being only a pro-Kurdish party and has tried to establish itself as a secular, left-wing party with a message that could appeal to a broader constituency, its start was rather clumsy. On the one hand, its relationship with the Kurdish Workers' Party (PKK) was-and remains-a sensitive issue. In the eyes of many Turks, the HDP was merely the political wing of a terrorist organization, and this shattered HDP's hopes of enlarging its appeal among Turkish voters. For its part, the PKK leadership was not comfortable with a rise of a strong civilian voice within the Kurdish political movement that could challenge its hegemonic position. Furthermore, the HDP's relationship with the AKP government was ambivalent In May and June 2013, the HDP appeared unable to capture the moment and did not fully embrace the Gezi Park 
protests, which shook the AKP government and became a source of inspiration for a wide array of left-wing social movements. The HDP appeared to be taking equal distance between the AKP government and the demonstrators and arguably saw the Gezi protests as a potential threat to the Kurdish peace process. ${ }^{3}$ This led some to believe that the Kurdish political movement would be willing to ignore growing authoritarian tendencies of the AKP government in return for a package deal regarding the Kurdish question in the ongoing peace negotiations. ${ }^{4}$ In particular, the transformation of the constitutional reform debate from a debate on the promotion of democratic reform and human rights into a debate about the introduction of a presidential system had irked secular and liberal Turks. It was therefore feared that the Kurdish peace process could provide an opportunity for a "grand bargain" in which Kurdish demands on mother tongue public education and devolution would be met under the condition of support for the introduction of a presidential system in Turkey.

The first positive signal of the HDP's ability to navigate through the treacherous waters of Turkish politics was given in the August 10, 2014 presidential elections, when the HDP candidate and party co-president Selahattin Demirtaş received 9.76 percent of the vote. With this result, the HDP outperformed its predecessors and came very close to the critical ten percent electoral threshold, which would be in play in the 2015 parliamentary elections. The party also presented a charismatic figurehead. Demirtaş, a member of the Turkish National Assembly and former mayor of Diyarbakir, emerged as a political figure that appealed beyond the traditional base of the proKurdish political movement and injected some long-needed charisma into the Turkish opposition scene.

Nonetheless, the HDP continued to be viewed with suspicion by some in the country's secular elite. This grew when, under the leadership of Demirtaş, the HDP took the decision to run in the elections as a party and not support independent candidates. This decision appeared to the eyes of many as very risky, meaning that it might fail to enter parliament and therefore pave the way for the continued political hegemony of the AKP. This would be the case because if it failed to cross the ten percent threshold it would collect zero seats instead of the 20-25 normally won by independent candidates. The vast majority of these seats would then pass to the AKP, and this would greatly facilitate President Erdoğan's effort to win a qualified majority sufficient to put forward the introduction of a presidential system. The absence of a pro-Kurdish party from the Turkish National Assembly would also lead to a major legitimacy crisis. ${ }^{5}$

To dispel any suspicions about collusion with the AKP, the HDP and copresident Demirtaş increased criticism toward the AKP government and President Erdoğan. Demirtaş's promise "Seni başkan yaptırmayacağız (We shall not make you president)," meaning that the HDP would never facilitate 
Erdoğan's plans for constitutional reform with the aim to introduce a presidential system, became one of the defining moments of the election campaign. Meanwhile the HDP scaled up its efforts to appeal to three crucial voter groups that did not count among the core voters of its predecessor proKurdish political parties. The first was conservative voters of Kurdish ethnic descent, who in the past backed mainstream conservative Turkish political parties and had been core supporters of the AKP since its meteoric rise to power in 2002. The second group was voters of Kurdish ethnic descent who had immigrated to Turkey's big cities, Istanbul, Ankara and Izmir, who also normally voted for mainstream political parties. The third group consisted of liberal secular voters of Turkish or at least non-Kurdish ethnic descent who had grown disillusioned by all the mainstream Turkish political parties and believed that the Turkish political party system could not represent them. Strengthening its appeal among all three groups was sine qua non for the HDP to cross the ten percent threshold. The party was rebranded as a "Türkiyeli" party, representing all the ethnic groups of the Republic of Turkey, including the Turks.

The solution of the Kurdish problem was thus defined in the context of the resumption of the democratization process and the advancement of human rights protection for all Turkish citizens. Thus, the HDP ceased to be simply a "pro-Kurdish" party and aimed to grow into a party that addressed the grievances and concerns of all dispossessed Turkish citizens, no matter their ethnicity. It also incorporated in its political agenda key demands of the Gezi movement on human and environmental rights protection, building a left-of-center profile. In particular, it signaled that it would not trade concessions regarding Kurdish minority rights for acquiescence to the growing authoritarian tendencies of the AKP government and the introduction of a presidential system by constitutional reform. Launching an election campaign not limited to the grievances of the Kurdish minority of the country was no easy task, as the party had to build confidence among Turkish secularists. The HDP appealed to the Turkish secular middle class, which was strongly disappointed by the policies of the AKP government and opposed the introduction of a presidential system, as it saw this development as a further step toward the decline of the quality of Turkish democracy. Appealing to the secular middle class also required taking a more assertive stance against PKK terrorism. Gaining credibility on this issue without losing support among Kurdish voters required very delicate moves by Demirtaş.

\section{The HDP in the 2015 elections}

In 2015, these efforts bore some fruit. In the June 7, 2015 elections, the HDP comfortably crossed the ten percent threshold and collected 6,058,489 votes, 13.12 percent of the total. This performance secured 80 seats in the 550 
member National Assembly, more than tripling its result compared to the previous elections of 2011. A closer look into the results district by district would confirm that the party was able to substantially increase its appeal among all three aforementioned groups. Moreover, the increase of the HDP's vote and its entry to the parliament was one of the main reasons for the failure of the AKP to secure a parliamentary majority for the first time since $2002 .^{6}$

These results briefly raised hopes that a non-AKP coalition government could be formed, bringing the HDP into power. Yet these hopes were soon dashed, as detailed in this special section by Ersin Kalaycığlu. The failure of the three opposition parties, the Republican People's Party (Cumhuriyet Halk Partisi [CHP]), the Nationalist Action Party (Milliyetçi Hareket Partisi [MHP]) and the HDP to form a coalition government was mainly due to the categorical opposition of the far-right nationalist MHP to join any coalition with the HDP. This played into the hands of the AKP and President Erdoğan who took an increasingly active role in post-election political maneuvering. They argued that Turkey could not afford instability and weak coalition governments following 13 years of single-party AKP governments that were instrumental in securing stability and economic growth. Pressure to form a strong, single-party government increased in July, when the end of the ceasefire with the PKK and the resumption of violence raised interethnic tensions and brought again the specter of war after several years of relative calm.

Another key lever in AKP's efforts to recover lost ground against the HDP was its claims about the relationship between the HDP and the PKK. As the Kurdish peace process stumbled and hostilities between Turkish security and the PKK forces recurred, the AKP and pro-government media persistently accused the HDP of being an accomplice, if not a puppet, of a terrorist organization. Despite repeated statements by Demirtaş that aimed to clearly differentiate the HDP and the PKK, this did not gain much political traction due to variety of opinions within the party as well as interventions by the interred PKK leader Abdullah Öcalan and the PKK leadership based in Kandil in northern Iraq. The HDP appeared unable to convincingly distinguish itself from the PKK and terrorist violence and thus prove that it could really lead and represent Turkey's Kurdish minority, let alone ethnic Turks.

In addition to violence between the PKK and the Turkish state, terrorist attacks both prior to and after the June elections affected the HDP and contributed to a polarized environment. In particular, three major terrorist attacks targeted the HDP. On June 5, 2015, four persons were killed and about 100 were injured by two bomb explosions during the main election rally of the HDP in the city of Diyarbakir. On July 20, 2015, a suicide bomb attack killed 33 Turkish and Kurdish youths in Suruç, a town next to the Syrian border. The victims were about to cross the border and offer 
humanitarian aid to the residents of Kobane, one of Syria's most war-torn towns which had become a symbol for Kurdish resistance against the advancing jihadist forces of the "Daesh" or "Islamic State of Iraq and Syria (ISIS)." Finally, on October 10, 2015, two suicide bombers targeted a demonstration in Ankara that was organized by the HDP and other leftist organizations to demand a peaceful resolution of the Kurdish issue. More than 100 people were killed and 400 were injured in what proved as the bloodiest single act of terrorism in republican Turkish history. However, the attacks on the HDP did not prove beneficial from the electoral point of view. While all three were linked with "Daesh" cells in Turkey, in particular one in the eastern city of Adiyaman, public opinion did not consider the government responsible for negligence in tracking such terrorist activities. On the contrary, many backed the government's call for stability and strong rule. All three terrorist attacks polarized the already strained relations among the conservative, the secular and the Kurdish elements within Turkey and made the appeal to national unity under a strong AKP government more attractive.

The results of the November 1 parliamentary elections demonstrate that the AKP government's rhetoric did in fact resonate with the three crucial voter groups that had shifted their support toward the HDP in the June 2015 elections and mobilized voters who had abstained from the June elections. In the latter elections, the HDP collected 5,148,085 votes, 10.76 percent of the total, thus securing 59 seats in the National Assembly. Losing over two percent of the vote or about 900,000 votes and 21 seats was certainly a major disappointment. It appeared that the HDP suffered losses in all three critical voter groups, which had voted for it for the first time in the June 7, 2015 elections. A sizeable part of conservative and immigrant Kurdish voters who had voted for the HDP for the first time were convinced by the AKP that instability was the biggest threat for their interests. Many abstained from the elections or voted for a strong, single-party AKP government. $^{7}$ Scaling up the rhetoric against the HDP and identifying it with the PKK found resonance with a substantial part of Turkish public opinion, which was ambivalent in its stance vis-à-vis the HDP. Raising the specter of military confrontation also made it more difficult for members of the Turkish secular middle class to vote for a party which in the eyes of many was still identified with Kurdish nationalism and secessionism.

Nevertheless, one should put the electoral performance of November 1 into perspective. Despite the electoral decline and the disillusionment that this caused, the HDP remained comfortably above the ten percent threshold, establishing itself as the fourth biggest political party in the Turkish political scene. Its prospects will greatly depend on its adaptability to the multiple challenges it faces, the leadership skills of Demirtaş and the overall course of Turkish politics. The consolidation of the transformation of the HDP into a center-left party aiming to give voice and represent all the dispossessed of 
Turkish society would boost the chances for the resolution of the Kurdish conflict. Yet developments remain anything but promising. On November 28, 2015, the president of the Diyarbakir Bar Association and prominent human rights activist, Tahir Elçi, was assassinated during a press conference in Diyarbakir. Some weeks before his assassination, Elçi had attracted the ire of Turkish nationalists and had been even detained. The reason was his claim in a TV talk show that "PKK is not a terrorist organization." This brought to mind some of the darkest pages of Turkish politics of the 1990s and pointed at the reversibility of all the positive steps made over the last decade. As the legitimate political representative of the Kurdish political movement, the HDP remains an indispensable actor for the resumption of the peace talks, as well as for the rejuvenation of the Turkish left. Given the traditions of Turkish politics, much of the burden of this will fall onto the shoulders of the party's leader, Selahattin Demirtaş. The success of the HDP to remain at the center stage of Turkish politics may be one of the last chances for the peaceful resolution of Turkey's Kurdish question.

\section{Disclosure statement}

No potential conflict of interest was reported by the author.

\section{Notes}

1. Grigoriadis, "Political Participation of Turkey's Kurds and Alevis," 448-53.

2. According to Article $68 \$ 4$ :

The statutes and programs, as well as the activities of political parties shall not be contrary to the independence of the State, its indivisible integrity with its territory and nation, human rights, the principles of equality and rule of law, sovereignty of the nation, the principles of the democratic and secular republic; they shall not aim to promote or establish class or group dictatorship or dictatorship of any kind, nor shall they incite citizens to crime.

3. See, for example, Yavuz, "Demirtaş."

4. Bursal1, "Seçim Sonrasi-3."

5. Gürsel, "Kürtler Her Durumda Kazanıyor."

6. See KONDA, KONDA 7 Haziran. Sandik ve Seçmen Analizi.

7. On these, see KONDA, KONDA Kasım '15 Seçim Barometresi.

\section{Notes on contributor}

Ioannis N. Grigoriadis received his $\mathrm{PhD}$ from the University of London in 2005 and has held the Jean Monnet Chair of European Studies at the Department of Political Science \& Public Administration, Bilkent University since 2010. He has taught at British, Greek and Turkish universities and has held research positions in Germany, Greece and the UK. His research interests include European and Middle Eastern politics, nationalism, energy and democratization. He has authored two 
books, Trials of Europeanization: Turkish Political Culture and the European Union (London \& New York: Palgrave Macmillan, 2009) and Instilling Religion in Greek and Turkish Nationalism: A "Sacred Synthesis" (London \& New York: Palgrave Macmillan, 2012).

\section{Bibliography}

Bursalı, Orhan. “Seçim Sonrası-3: HDP-AKP İlişkisi Ne Olur?” Cumhuriyet, March 29, 2015.

Grigoriadis, Ioannis N. "Political Participation of Turkey's Kurds and Alevis: A Challenge for Turkey's Democratic Consolidation." Southeast European and Black Sea Studies 6, no. 4 (2006): 445-461.

Gursel, Kadri. “Kürtler Her Durumda Kazanıyor.” Al Monitor, January 23, 2015.

KONDA 7 Haziran Sandik ve Seçmen Analizi. Istanbul: KONDA Araştırma ve Danışmanlık, 2015.

KONDA Kasım '15 Seçim Barometresi: 1 Kasım Sandık ve Seçmen Analizi. Istanbul: KONDA Araștırma ve Danıșmanlık, 2015.

Yavuz, Ramazan. "Demirtaş: Süreci Baltalamak Isteyenlerle Yanyana Olmayız." Milliyet, June 1, 2013. 